\title{
DETERMINAN JUMLAH LIMBAH KOTA YANG DIHASILKAN DARI SEMBILAN NEGARA EKONOMI BERKEMBANG DI ASIA TAHUN 2010-2017
}

\author{
(Determinant Amount of Muncipal Waste Generated from Nine Developing Economy \\ Countries in Asia at 2010-2017 )
}

\author{
Lia Khairunnisak ${ }^{1}$, Timbang Sirait ${ }^{2}$ \\ Politeknik Statistika STIS ${ }^{1}$ \\ Politeknik Statistika STIS ${ }^{2}$ \\ Jl. Otto Iskandardinata No. 64C, Jakarta 13330 \\ E-mail: 16.9236@stis.ac.id
}

\begin{abstract}
ABSTRAK
Limbah Kota merupakan masalah serius yang harus dihadapi oleh seluruh negara yang ada di dunia. Peningkatan jumlah limbah kota setiap tahunnya juga seiring dengan perkembangan wilayah perkotaan di suatu negara. Limbah kota yang dihasilkan oleh setiap negara ditemukan meningkat cepat jumlahnya pada negara dengan ekonomi berkembang. Asia diketahui sebagai benua penghasil limbah terbesar di dunia, dimana sebagian negara berkembangnya diketahui sebagai penyumbang limbah terbesar dari total keseluruhan limbah yang dihasilkan dari seluruh dunia. Data yang digunakan merupakan data dari Sembilan negara ekonomi berkembang yang dipilih menggunakan klasifikasi dari UNCTAD berdasarkan status pembangunan (Indonesia, Malaysia, Cina, Kirgistan, Kazakhstan, Azerbaijan, Armenia, Turki, Singapura). Tujuan dari penelitian ini adalah untuk mengetahui faktor-faktor yang mempengaruhi jumlah limbah kota yang dihasilkan di sembilan negara ekonomi berkembang terpilih yang ada di Asia. Metode analisis yang digunakan yaitu analisis regresi data panel model fixed effect - weight least square (FEM-WLS). Hasil analisis menunjukkan bahwa variabel jumlah penduduk perkotaan dan Foreign Direct Investment (FDI) berpengaruh secara signifikan terhadap jumlah limbah kota yang dihasilkan oleh sembilan negara ekonomi berkembang yang terpilih.
\end{abstract}

Kata kunci: limbah kota, limbah, data panel, regresi data panel.

\begin{abstract}
Municipal waste is a serious problem that must be faced by all countries in the world. The increase in the amount of municipal waste each year is also in line with the development of urban areas in a country. Municipal waste generated by each country is found to be increasing rapidly in developing economies. Asia is known as the continent that generates the largest waste in the world, where some of its developing countries are known to be the largest waste contributors to the total waste generated from around the world. The data used is data from nine developing economies selected using the classification from UNCTAD based on development status (Indonesia, Malaysia, China, Kyrgyzstan, Kazakhstan, Azerbaijan, Armenia, Turkey, Singapore). The purpose of this study was to determine the factors that influence the amount of municipal waste generated in nine selected developing economies in Asia. The analysis method used is the regression analysis of panel data model fixed effect - weight least square (FEM-WLS). The results of the analysis show that the variable urban population and Foreign Direct Investment (FDI) has a significant effect on the amount of urban waste generated by the nine selected developing economies.
\end{abstract}

Keywords: municipal waste, waste, panel data, panel data regression.

\section{PENDAHULUAN}

Asia merupakan benua terbesar di dunia dengan luas wilayah 45 juta $\mathrm{km}^{2}$ atau setara dengan 17,2 mil2. Sekitar 59,76\% penduduk bumi berada di Benua Asia, yang mana sekitar 50,3\% dari total seluruh penduduknya tinggal di perkotaan pada tahun 2019. Selain itu, berdasarkan publikasi IMF dalam Regional Economic Outlook Asia-Pacific menunjukkan bahwa perekonomian di Asia 
pada tahun 2017 tumbuh sebesar 5,7\% naik 0,3\% dari tahun sebelumnya dan menjadi wilayah dengan pertumbuhan ekonomi tercepat di dunia yang menyumbang lebih dari $60 \%$ dari pertumbuhan global dimana tiga perempatnya berasal dari Cina dan India. Diketahui pula bahwa konsumsi dan investasi menjadi kontributor utama dalam perekonomiannya.

Wilayah yang luas, populasi yang tinggi dan pertumbuhan perekonomian yang cepat menyebabkan Asia menghadapi beberapa masalah salah satunya mengenai limbah. Limbah diketahui menjadi masalah penting dalam tujuan pembangunan berkelanjutan (SDGs). Salah satu masalah jenis limbah yang di hadapi oleh setiap negara di seluruh dunia terutama Asia yaitu limbah kota. Setiap harinya, total limbah kota yang dihasilkan dari seluruh dunia yang berbentuk padat mencapai 35 juta ton per hari dan diperkirakan akan meningkat pada tahun 2025 menjadi 60 juta ton per hari (ISWA, 2014). Dari total limbah kota tersebut, 33\% dari jumlah totalnya diketahui tidak dikelola dengan cara yang ramah lingkungan (World Bank). Diketahui pula bahwa setiap orang menghasilkan jenis limbah ini setiap harinya rata-rata sebesar $0,74 \mathrm{~kg}$ dengan rentang kisaran antara 0,11 kg hingga 4,54 kg (World Bank).

Berdasarkan publikasi World Bank pertumbuhan total limbah ditemukan mengalami peningkatan dengan tingkat yang lebih cepat ketika terjadi perubahan pertambahan pendapatan di negara berpenghasilan rendah dibanding negara berpenghasilan tinggi. Hal ini disebabkan karena negara-negara berpenghasilan rendah mengumpulkan sekitar $48 \%$ sampah di kota-kota, $26 \%$ di daerah pedesaan, dan hanya $4 \%$ yang didaur ulang. Selain itu, penduduk perkotaan yang ada di Asia mencapai $43 \%$ dari total penduduk secara keseluruhan dan kota-kota yang ada di Asia diperkirakan akan menghasilkan limbah 1,8 miliar ton pada tahun 2025 (Asia Waste Management Outlook, UNEP, 2017).

Menurut World Bank wilayah Asia Timur dan Pasifik menghasilkan jumlah limbah sebesar 468 juta ton pada tahun 2016, dengan tingkat rata-rata 0,56 kg/kapita/hari yang mana lebih rendah dari rata-rata global sebesar $0,74 \mathrm{~kg} / \mathrm{kapita} / \mathrm{hari}$. Selain itu, limbah yang dihasilkan di wilayah ini sekitar 77 persennya dihasilkan di wilayah perkotaan. Jumlah total limbah yang dihasilkan di wilayah Asia Timur dan Pasifik sekitar 47 persennya dihasilkan dari Cina, dimana Cina menghasilkan jumlah limbah sebesar $0,43 \mathrm{~kg} / \mathrm{kapita} / \mathrm{hari}$ yang lebih rendah dari rata-rata limbah perkapita yang dihasilkan di wilayah Asia Timur dan Pasifik.

Faktor- faktor yang menyebabkan tingginya jumlah limbah kota di Asia khususnya negara berkembang menurut Agamuthu et al., (2007) dan World Bank dikarenakan pertumbuhan cepat daerah perkotaan, migrasi desa-kota, peningkatan pendapatan perkapita, perubahan pola konsumsi, perkembangan perekonomian, derajat industrialisasi, perilaku masyarakat, dan iklim lokal.

Penelitian yang berkaitan dengan limbah kota pernah dilakukan oleh Karousakis (2006) hasilnya menunjukkan variabel PDB perkapita, urbanisasi, indeks kebijakan dan legislasi limbah berpengaruh terhadap jumlah limbah kota. Penelitian lain yang dilakukan oleh Athanasios et al. (2018) menunjukkan PDB perkapita, GNI perkapita, konsumsi perkapita, kepadatan penduduk dan tingkat pekerja memiliki korelasi yang tinggi serta berpengaruh terhadap jumlah limbah kota. Kemudian penelitian terdahulu dengan topik yang sama lainnya dari Mazzanti dan Zoboli (2008) hasilnya menunjukkan variabel konsumsi, kepadatan penduduk, dan indeks kebijakan lingkungan berpengaruh terhadap jumlah limbah kota. Kemudian penelitian yang dilakukan oleh Degli Antoni dan Marzetti (2019) hasil penelitian ini menunjukkan variabel yang signifikan secara statistik yang berpengaruh terhadap limbah padat kota perkapita dan daur ulang yaitu hanya pendapatan perkapita. Penelitian dari Gnonlonfin et al. (2017), hasil penelitian ini menunjukkan di negara dengan pendapatan tinggi menunjukkan pendapatan, openness, impor/GDP, industri, jasa, tingkat urbanisasi, kapadatan penduduk, iklim dan wanita yang bekerja berpengaruh terhadap limbah padat kota. Di negara berpendapatan menengah menunjukkan pendapatan, openness, tingkat urbanisasi, wanita yang bekerja, iklim berpengaruh terhadap jumlah limbah kota.

Karena kurangnya penelitian mengenail limbah kota yang ada di negara perekonomian berkembang maka penelitian mengenai masalah ini perlu dilakukan. Berdasarkan uraian tersebut maka tujuan dari penelitian ini adalah untuk mengetahui faktor-faktor yang 
memengaruhi jumlah limbah kota yang dihasilkan di sembilan negara ekonomi berkembang terpilih yang ada di Asia.

\section{METODE}

Data panel menurut Hsio (2014) merupakan data set yang mengikuti sampel individu tertentu dari waktu ke waktu, sehingga memberikan banyak pengamatan pada setiap individu dalam sampel. Bentuk dari model regresi data panel menurut Greene (2003) sebagai berikut :

$$
\begin{aligned}
& y_{i t}=\boldsymbol{X}_{i t}^{\prime} \beta+z_{i}^{\prime} \alpha+\varepsilon_{i t} \text { atau } \\
& y_{i t}=\boldsymbol{X}_{i t}^{\prime} \beta+c_{i}+\varepsilon_{i t}, i=1,2,3, \ldots, \mathrm{n} ; t=1,2,3, \ldots, \mathrm{T}
\end{aligned}
$$

Dimana $y_{i t}$ merupakan variabel tak bebas observasi ke-it. $\boldsymbol{X}_{i t}^{\prime}$ merupakan obeservasi ke-it variabel bebas dengan ukuran $\mathrm{K} \times 1 . z_{i}^{\prime} \alpha$ atau $c_{i}$ merupakan heterogenitas atau efek individu, berisi konstanta dan kumpulan individu yang dapat diobseravsi maupun tidak serta konstan sepanjang waktu. $\varepsilon_{i t}$ merupakan error model.

Model regresi data panel ini akan diaplikasikan pada data sekunder dari kesembilan negara ekonomi berkembang yang ada di Benua Asia sejak tahun 2010-2017. Model persamaan regresi data panel yang dirumuskan dalam penelitian ini sebagai berikut :

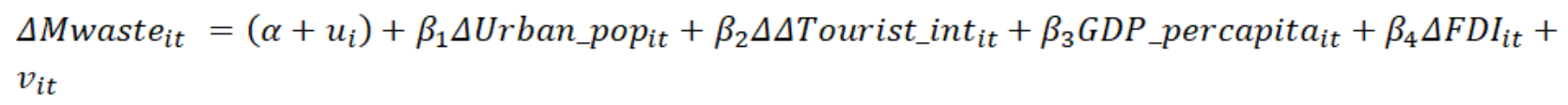

\section{Cakupan Penelitian}

Data yang digunakan merupakan data panel dari negara dengan perekonomian berkembang yang ada di Benua Asia sejak tahun 2010 hingga tahun 2017. Karena masalah keterbatasan data, maka data negara ekonomi berkembang yang terpilih dan tersedia secara lengkap pada sumber data diperoleh 9 negara (Indonesia, Malaysia, Cina, Kirgistan, Kazakhstan, Azerbaijan, Armenia, Turki, Singapura) yang dipilih berdasarkan klasifikasi kelompok status pembangunan dari United Nations Conference on Trade And Development (UNCTAD). Dimana klasifikasi pada kelompok status pembangunan dari UNCTAD terdapat 3 jenis yaitu negara ekonomi berkembang, maju dan transisi. Data dalam penelitian ini merupakan data sekunder yang disediakan oleh United Nations Statistics Division (UNSD) dan World Bank. Selain itu variabel bebas yang digunakan dalam penelitian ini adalah jumlah penduduk perkotaan, jumlah wisatawan mancanegara, PDB perkapita, dan Foreign Direct Investment (FDI). Sedangkan variabel tak bebas yang digunakn adalah jumlah limbah kota.

\section{HASIL DAN PEMBAHASAN}

\section{Limbah Kota}




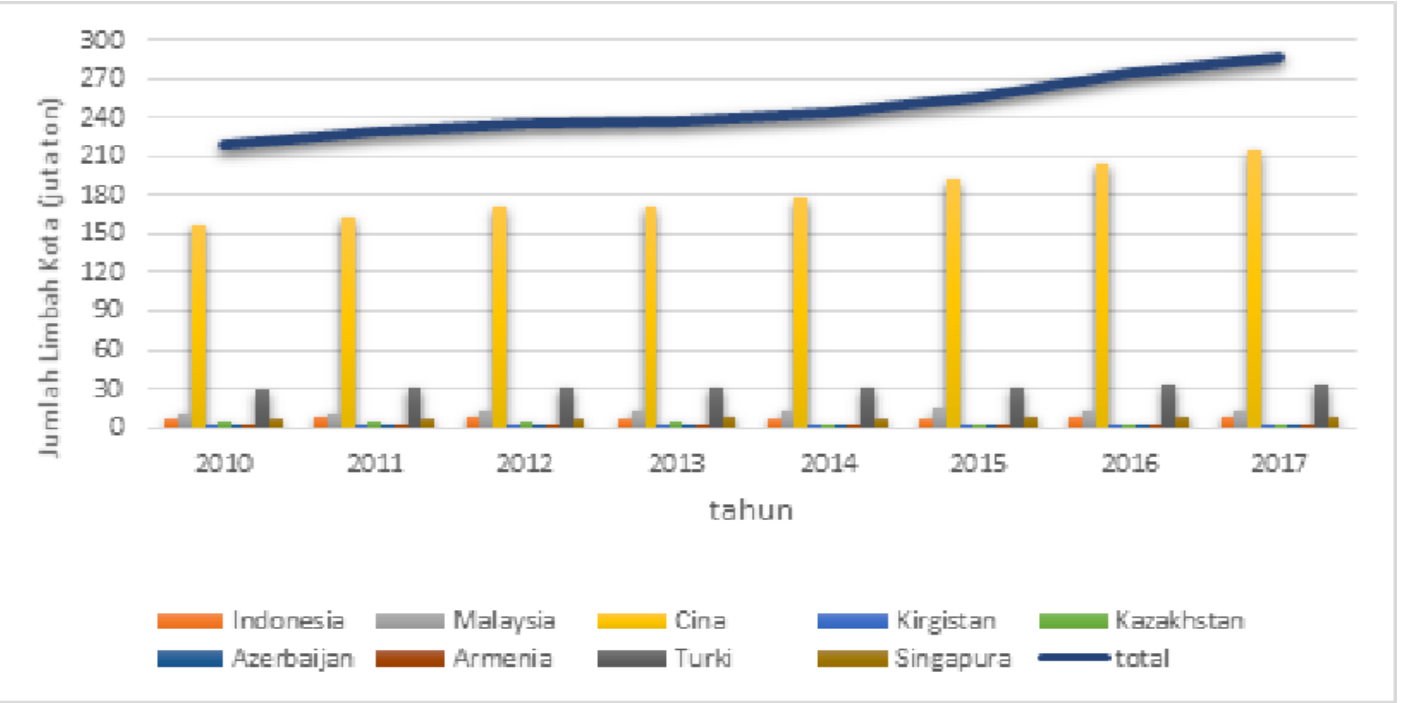

Gambar 1. Jumlah Limbah Kota di Sembilan Negara Ekonomi Berkembang 2010-2017

Dari grafik di atas menunjukkan nilai total limbah kota yang dikumpulkan dari sembilan negara ekonomi berkembang di Asia menunjukkan kenaikan secara terus menerus dari tahun 2010 hingga tahun 2017. Pada tahun 2010 total jumlah limbah kota sebesar 219,308 juta ton kemudian naik menjadi 287,286 juta ton pada tahun 2017 dimana selisihnya lebih dari 50 juta ton selama beberapa tahun tersebut.

Cina menjadi salah satu negara terbesar yang menghasilkan limbah kota di dunia. Menurut Dong et al. (2001) dalam Xiao et al. (2006) diketahui Cina setiap tahunnya menghasilkan limbah kota $29 \%$ dari jumlah total seluruh dunia. Dapat dilihat dari diagram yang disediakan bahwa jumlah limbah kota yang ada di Cina dari tahun 2010 hingga tahun 2017 memiliki tren yang naik. Selain itu jumlah limbah kota yang dihasilkan oleh Cina terlihat lebih besar jumlahnya dibanding negara-negara lainnya. Jumlah terbesar limbah kota yang dihasilkan Cina dalam rentang waktu tahun 2010 hingga tahun 2017 terjadi pada tahun 2017 sebesar 215,209 juta ton. Selanjutnya negara yang menghasilkan jumlah limbah kota terbesar setelah Cina diikuti oleh Turki, Malaysia, dan Indonesia yang setiap tahunnya dari tahun 2010 hingga tahun 2017 menghasilkan limbah kota yang semakin banyak. Negara terendah yang menghasilkan limbah kota adalah Armenia dimana dari tahun 2010 hingga tahun 2017 jumlah limbah kota yang dihasilkan oleh negara ini berkisar antara nilai 0,3 juta ton hingga 0,5 juta ton.

\section{Penduduk Perkotaan}

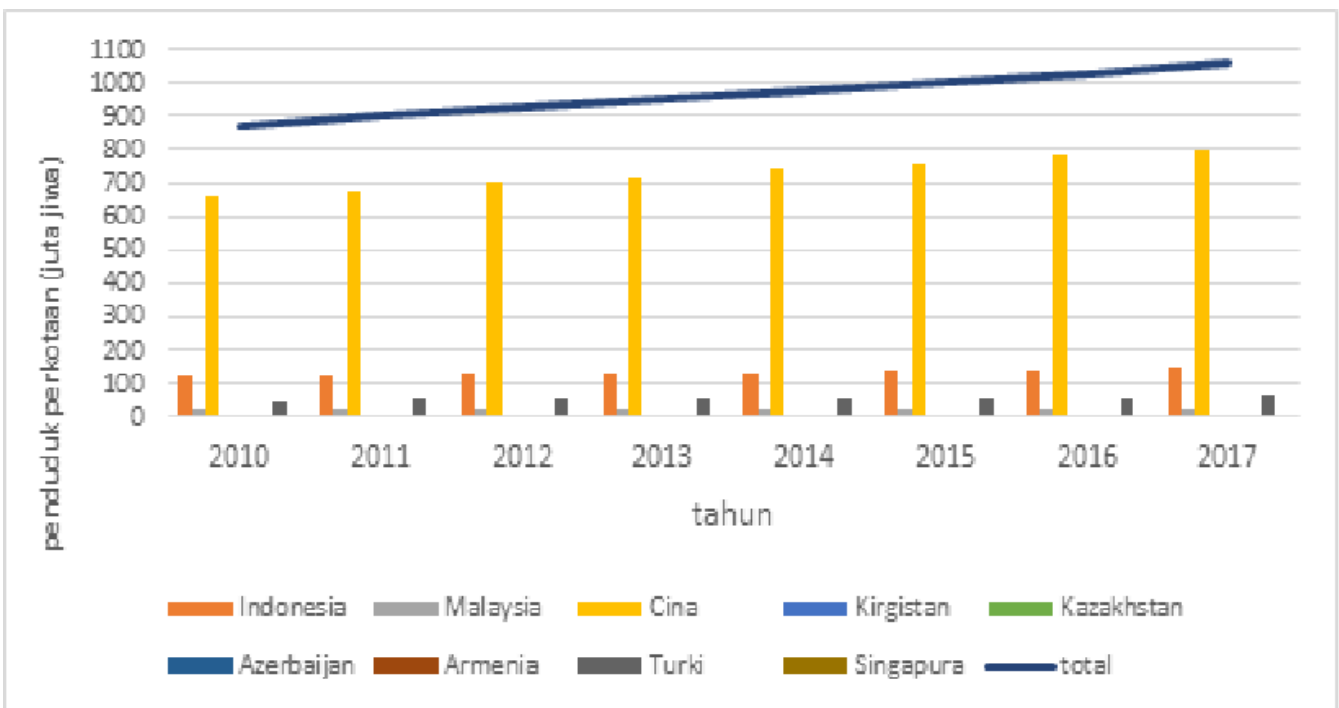

Gambar 2. Penduduk Perkotaan Kota di Sembilan Negara Ekonomi Berkembang 2010-2017 
Pada tahun 2010 total jumlah penduduk perkotaan dari sembilan negara tersebut sebanyak 873,373 juta jiwa dan meningkat pada tahun 2017 menjadi 1057,719 juta jiwa atau 1,058 miliar jiwa. Dari diagram diatas menunjukkan Cina merupakan negara dengan penduduk terbesar di dunia mengalami kenaikan jumlah penduduk perkotaan yang tinggi dibanding negara lainnya. Pada tahun 2010 jumlah penduduk perkotaan di negara ini mencapai 658,499 juta jiwa kemudian pada beberapa tahun berikutnya pada tahun 2017 mencapai 803,555 juta jiwa. Selama 7 tahun Cina mengalami pertambahan jumlah penduduk perkotaan sekitar 150 juta jiwa.

Selanjutnya negara dengan jumlah penduduk perkotaan yang tertinggi setelah Cina yaitu Indonesia. Pada tahun 2010 jumlah penduduk perkotaan yang ada di Indonesia sebesar 120,709 juta jiwa kemudian pada tahun 2017 jumlah penduduk perkotaan di Indonesia menjadi 144,653 juta jiwa. Negara-negara lainnya juga mengalami kenaikan jumlah penduduk perkotaan akan tetapi tidak sebesar kenaikan jumlah penduduk perkotaan di Cina dan Indonesia. Negara yang memiliki jumlah penduduk perkotaan yang paling sedikit adalah Armenia dan Kirgistan.

\section{Wisatawan Mancanegara}

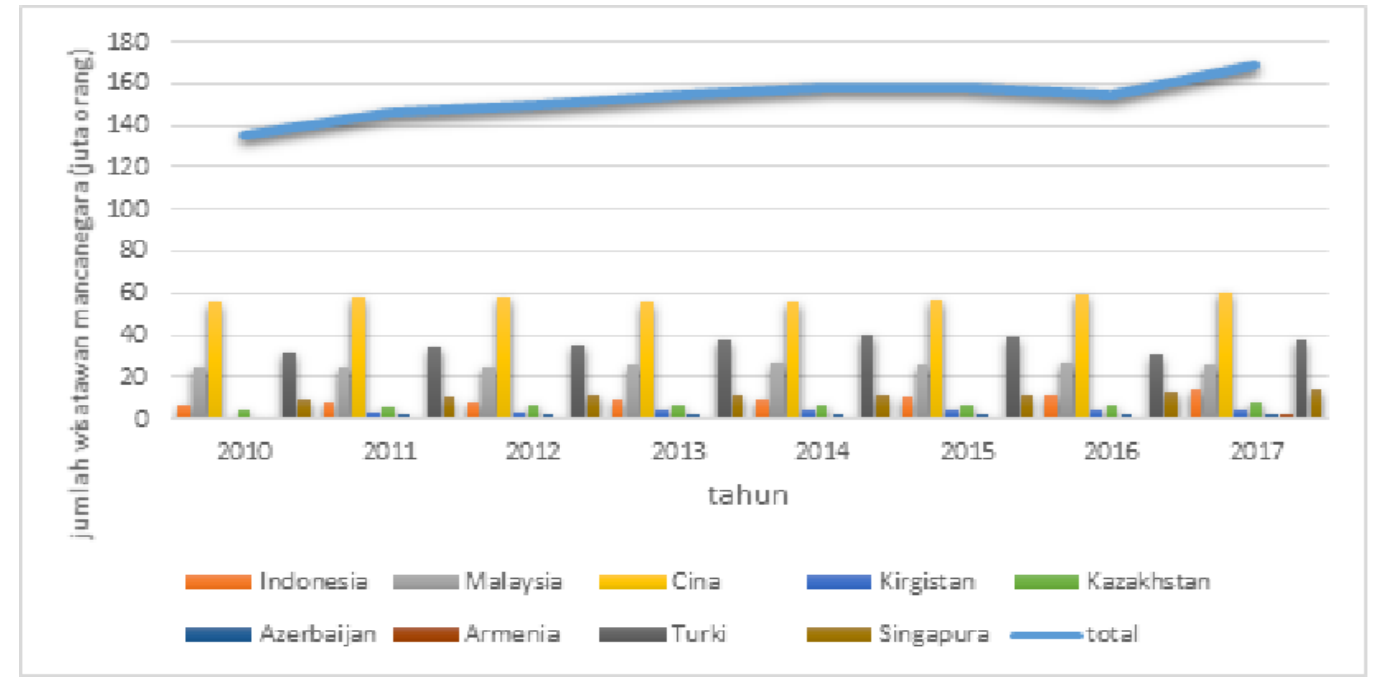

Gambar 3. Wisatawan Mancanegara di Sembilan Negara Ekonomi Berkembang 2010-2017

Dapat dilihat dari grafik mengenai total jumlah wisatawan yang datang dari tahun 2010 hingga tahun 2017 cenderung meningkat. Pada awalnya di tahun 2010 total jumlah wisatawan mancanegara yang datang ke sembilan negara tersebut sebanyak 135,054 juta orang yang kemudian naik pada tahun 2017 menjadi 168,45 juta orang. Dari beberapa tahun tersebut jumlah wisatawan yang datang ke sembilan negara tersebut mengalami kenaikan sekitar 30 jutaan orang.

Dari sembilan negara tersebut yang memiliki jumlah pengunjung wisatawan mancanegara yang terbanyak adalah Cina. Pada tahun 2010 jumlah wisatawan mancanegara yang datang ke negara ini sebanyak 55,664 juta orang dan pada tahun 2017 jumlahnya meningkat menjadi 60,74 juta orang.

Negara kedua yang memiliki jumlah kunjungan wisatawan mancanegara terbanyak setelah Cina adalah Turki, dimana jumlah wisatawan mancanegara yang berkunjung ke negara ini sebanyak 31,364 juta orang pada tahun 2010 dan pada tahun 2017 mencapai 37,601 juta orang..

Negara yang memiliki jumlah kedatangan wisatawan mancanegara yang terendah adalah Armenia. Pada tahun 2010 jumlah wisatawan mancanegara yang datang ke negara ini sebanyak 684 ribu orang kemudian jumlahnya terus naik hingga mencapai 1,495 juta orang pada tahun 2017. Jumlah kedatangan wisatawan mancanegara di negara ini dalam rentang waktu tersebut mengalami peningkatan sebesar 811 ribu orang.

\section{PDB Perkapita}




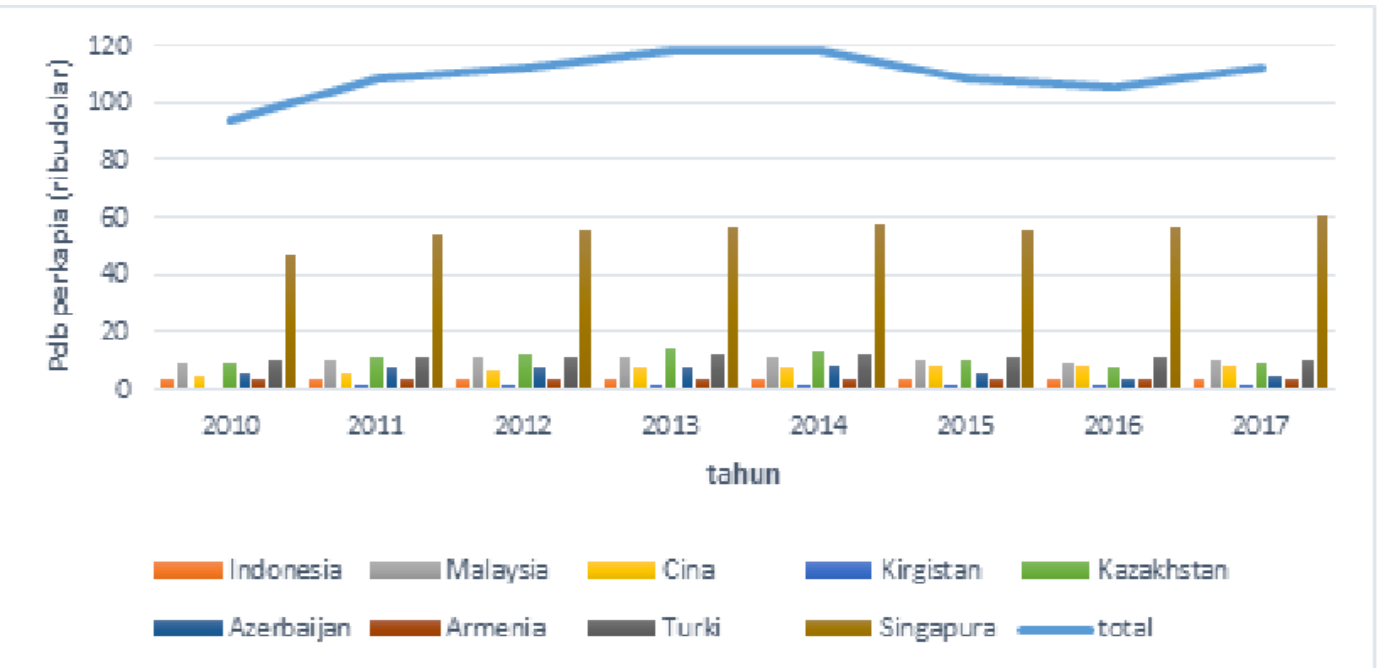

Gambar 4. PDB Perkapita di Sembilan Negara Ekonomi Berkembang 2010-2017

Perekonomian yang ada di benua Asia mengalami pertumbuhan yang cepat di beberapa negara. Dapat dilihat dari grafik di atas PDB perkapita dari sembilan negara tersebut mengalami fluktuasi tetapi cenderung meningkat dari tahun 2010 hingga tahun 2017. Pada awalnya di tahun 2010 total PDB perkapita di sembilan negara tersebut sebesar 93,634 ribu dollar, kemudian pada tahun 2017 jumlah total PDB perkapita di sembilan negara tersebut menjadi 112,214 ribu dollar. Hingga tahun 2010 sampai 2017 nilai PDB perkapita di sembilan negara tersebut paling banyak berada direntang 3 ribu hingga 8 ribu dollar, dan beberapa negara memiliki PDB perkapita di atas 10 ribu dollar. Diantara sembilan negara tersebut, Singapura memiliki PDB perkapita tertinggi dibandingkan yang lainnya. Kirgistan, berdasarkan diagram diatas menjadi negara yang memiliki PDB terendah. Selain kedua negara tersebut, PDB perkapita yang dihasilkan oleh negara lainnya berada pada rentang 3 ribu dollar hingga 13 ribu dollar pada tahun 2010 hingga tahun 2017.

\section{Foreign Direct Investment}

Total jumlah nilai FDI di sembilan negara perekonomian berkembang menunjukkan nilai negatif atau FDI inflow lebih besar dari pada FDI outflow yang artinya investasi langsung yang dilakukan ke luar negeri lebih kecil dibandingkan investasi langsung yang dilakukan ke dalam negeri di sembilan negara ini oleh seluruh negara lainnya. Pada tahun 2010 nilai selisih total FDI di sembilan negara ekonomi berkembang tersebut sebesar 224,878 miliar dollar yang bertanda negatif, kemudian cenderung naik pada tahun 2016 dan turun kembali pada tahun 2017 menjadi 114,216 miliar dollar yang bertanda negatif juga.

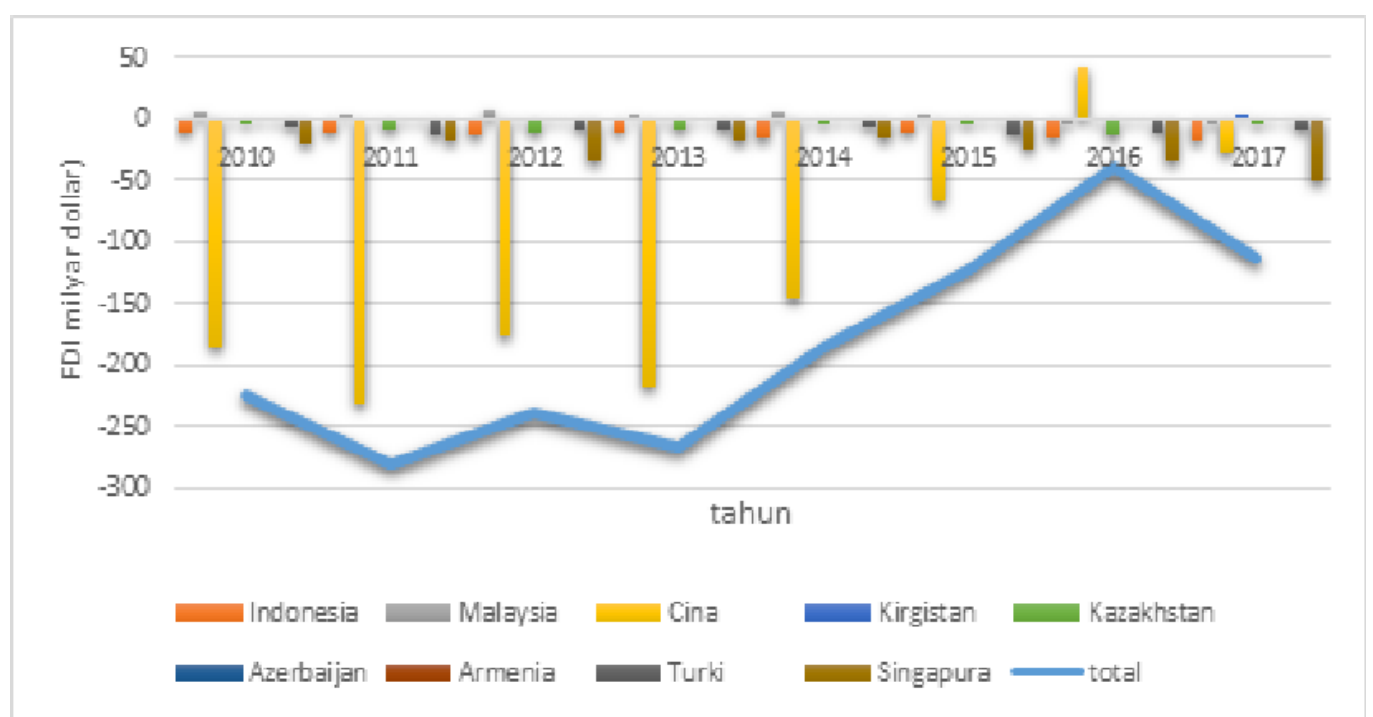

Gambar 5. FDI di Sembilan Negara Ekonomi Berkembang 2010-2017 
Cina merupakan negara dengan jumlah terbesar pada selisih nilai FDI inflow yang lebih besar dibandingkan FDI outflomnya. Akan tetapi nilai ini dari tahun 2010 hingga tahun 2017 semakin mengecil, hal ini menunjukkan Cina mengalami arus FDI outflow juga semakin besar. Pada tahun 2016 selisih nilai FDI Cina memiliki nilai 41,675 miliar dollar yang memiliki tanda positif, artinya pada tahun tersebut FDI outflow lebih besar nilainya dibanding FDI inflow. Karena yang terjadi pada arus FDI Cina tahun 2016, mengakibatkan pada tahun 2017 arus FDI keluar atau FDI outflow di negara-negara berkembang di Asia turun 9\% menjadi 350 miliar dollar, dan Asia Timur mengalami penurunan yang signifikan menjadi 250 miliar dollar karena yang terjadi pada arus FDI Cina tahun 2016 sejak pertama kali pernah terjadi pada tahun 2003 (UNCTAD, 2018). Kemudian pada tahun 2017 nilai FDI outflow kembali turun dan membuat nilai FDI inflow selisihnya 114,216 miliar dollar dengan bertanda negatif. Negara dengan selisih nilai FDI inflow lebih besar dibandingkan FDI outflow diantara sembilan negara tersebut yang terkecil adalah Kirgistan, Azerbaijan, dan Armenia.

\section{Faktor-Faktor yang Mempengaruhi Jumlah Limbah Kota}

Sebelum dilakukan pengujian regresi data panel, terlebih dahulu melakukan uji stasioneritas pada tiap-tiap variabel baik pada variabel tak bebas dan variabel bebasnya. Pengujian ini dilakukan seperti salah satu tujuannya yaitu untuk menghindari terjadinya spurious regression pada persamaan regresi data panel.

Tabel 1. Rangkuman hasil uji panel unit root-ADF

\begin{tabular}{|l|c|c|c|}
\hline \multicolumn{1}{|c|}{ Variabel } & Level & $1^{\text {st }}$ Difference & $2^{\text {nd }}$ Difference \\
\hline \multicolumn{1}{|c|}{1} & 2 & 3 & 4 \\
\hline Mwaste & Gagal tolak $\mathrm{H}_{0}$ & Tolak $\mathrm{H}_{0}$ & - \\
\hline Urban_pop & Gagal tolak $\mathrm{H}_{0}$ & Tolak $\mathrm{H}_{0}$ & - \\
\hline Tourist_int & Gagal tolak $\mathrm{H}_{0}$ & Gagal tolak $\mathrm{H}_{0}$ & Tolak $\mathrm{H}_{0}$ \\
\hline GDP_Perkapita & Tolak $\mathrm{H}_{0}$ & - & - \\
\hline FDI & Gagal tolak $\mathrm{H}_{0}$ & Tolak $\mathrm{H}_{0}$ & - \\
\hline
\end{tabular}

Setelah dilakukan pengujian panel unit root, dilakukan pengujian pemilihan model terbaik dengan menggunakan Uji Chow dan Uji Hausman. Hasil yang diperoleh dari kedua pengujian ini yaitu model fixed effect yang terpilih. Karena hasil yang diperoleh model fixed effect, Selanjutnya dilakukan pengujian untuk penentuan metode estimasi. Dimana dalam penentuan metode estimasi dilakukan pengujian struktur varians kovarians residual menggunakan Uji Lagrange Multiplier (Uji LM) dan pengujian cross sectional correlation menggunakan Uji Likelihoood Ratio (Uji LR). Hasil dari pengujian ini yaitu struktur varians kovarians bersifat heteroskedastis dan tidak terdapat cross sectional correlation. Sehingga metode estimasi yang digunakan adalah Weight Least Square (WLS).

Tabel 2. Rangkuman Hasil Uji Keberartian Model

\begin{tabular}{|c|c|c|c|c|}
\hline Variabel & t-statistik & p-value & \multicolumn{2}{|c|}{ Ringkasan Statistik } \\
\hline 1 & 2 & 3 & \multicolumn{2}{|c|}{4} \\
\hline C & $-30,449$ & $0,0041 *$ & \multirow{5}{*}{$\begin{array}{l}\text { R-squared } \\
\text { Adjusted R-squared } \\
\text { F-statistics } \\
\text { Prob (F-statistics) }\end{array}$} & \multirow{5}{*}{$\begin{array}{l}=0,7318 \\
=0,6532 \\
=9,3202 \\
=0,0000\end{array}$} \\
\hline Jumlah penduduk perkotaan & 32,925 & $0,0020^{*}$ & & \\
\hline Jumlah wisatawan mancanegara & $-0,3355$ & 0,7390 & & \\
\hline PDB perkapita & $-14,042$ & 0,1678 & & \\
\hline FDI & 34,833 & $0,0012 *$ & & \\
\hline
\end{tabular}

*) Signifikan pada taraf uji 5\%

Selain itu dilakukan pula pengujian asumsi klasik yaitu normalitas dan multikolinearitas. Pengujian normalitas menggunakan uji Jarque-Berra yang hasilnya untuk asumsi normalitas terpenuhi dengan nilai Jarque-Berra sebesar 0,9389 atau p-value sebesar 0,6253. Untuk pengujian mutikolinearitas menggunakan nilai Variance Inflation Factor (VIF) yang mana untuk keempat 
variabel bebas memiliki nilai VIF kurang dari 10, sehingga dapat disimpulkan bahwa tidak terdapat multikolinearitas.

Berdasarkan pengujian yang telah dilakukan, diperoleh model regresi data panel terbaik yaitu fixed effect model dengan metode estimasi Weight Least Square (WLS), berikut hasil yang diperoleh:

$$
\begin{aligned}
& \Delta \text { Mwaste }_{i t}= \\
& \left(-18,7153+\mu_{i}\right)+6,8709 \Delta \text { Urban_pop }_{i t}^{*}-0,0147 \Delta \Delta \text { Tourist_int }_{i t}-0,0345 \text { GDP_perkapita }_{i t}+ \\
& 0,0267 \Delta F D I_{i t}^{*}
\end{aligned}
$$

*) signifikansi pada taraf uji 5\%

Pada pengujian signifikansi secara parsial yaitu menggunakan uji $t$, hasilnya menunjukkan bahwa dari variabel bebas yang digunakan diperoleh dua variabel yang signifikan mempengaruhi variabel tak bebas. Jumlah penduduk perkotaan berpengaruh signifikan dan positif terhadap jumlah limbah kota yang dihasilkan di sembilan negara ekonomi berkembang. Hal ini sesuai dengan penelitian sebelumnya yang dilakukan oleh Karousakis (2007), Athanasios et al. (2018), serta Mazzanti dan Zoboli (2008) yang menggunakan lokus penelitian di negara ekonomi maju yaitu Eropa. Hal ini menunjukkan bahwa baik pada negara ekonomi maju maupun berkembang, faktor jumlah penduduk perkotaan mempengaruhi jumlah limbah kota yang dihasilkan di negara tersebut. Hal ini dikarenakan total timbunan limbah per tahun sebagian besar merupakan fungsi dari ukuran populasi (Jambeck et al., 2015). Selain itu, peningkatan limbah padat kota sejalan dengan pertumbuhan cepat area perkotaan dan migrasi populasi dari desa ke kota (urbanisasi) (A. Khajuria et al., 2010).

Wisatawan mancanegara tidak berpengaruh secara signifikan terhadap jumlah limbah kota yang dihasilkan di sembilan negara ekonomi berkembang tersebut. Hasil ini sesuai dengan penelitian yang dilakukan oleh Degli Antoni dan Marzetti (2019) yang hasil dari penelitiannya menunjukkan variabel wisatawan tidak berpengaruh secara signifikan. Hal ini terjadi karena wisatawan mancanegara yang datang ke kesembilan negara berkembang tersebut tidak hanya tinggal di daerah perkotaan saja dan kebanyakan dari para wisatawan mancanegara datang ke tempat yang memang merupakan daerah untuk wisata dimana hanya beberapa daerah di sebuah negara yang merupakan daerah tersebut. Selain itu, periode yang pendek seorang wisatawan menetap atau bermalam di suatu negara juga mempengaruhi hal ini.

Variabel PDB perkapita tidak berpengaruh secara signifikan terhadap jumlah limbah kota yang dihasilkan di sembilan negara ekonomi berkembang tersebut. Hasil ini sesuai dengan penelitian yang dilakukan oleh Gnonlonfin et al. (2017), dimana PDB perkapita tidak berpengaruh secara signifikan pada negara dengan pendapatan menengah tetapi berpengaruh secara signifikan pada negara dengan pendapatan tinggi. Menurut penelitian yang dilakukan Gnonlonfin et al. (2017), negara berpendapatan menengah rata-rata memiliki nilai PDB perkapita yang rendah, sehingga tidak terlalu memiliki pengaruh terhadap perekonomian karena dalam waktu dekat nilai PDB perkapita tersebut belum mencapai nilai titik balik potensialnya. Pertumbuhan PDB menyebabkan peningkatan limbah karena menunjukkan kemakmuran suatu negara, ketika kemakmuran suatu negara semakin meningkat maka dapat meningkatkan aktivitas konsumen dan ekspansi bisnis (Purcell dan Magette, 2009 dalam Athanasios, 2018). Meskipun PDB bukan untuk ukuran standar hidup, PDB dapat digunakan untuk menetapkan jumlah limbah kota di tingkat negara (Ahmad, 2012, Kumar et al., 2011 dalam Athanasios, 2018).

Variabel FDI berpengaruh secara signifikan dan positif terhadap jumlah limbah. Hasil ini juga sesuai dengan penelitian yang dilakukan oleh Gnonlonfin et al. (2017) yang hasilnya menunjukkan variabel FDI berpengaruh secara signifikan juga. Mengingat pentingnya FDI dalam perekonomian negara berkembang, hal ini menjadikan FDI memiliki pengaruh terhadap jumlah limbah kota yang dihasilkan. Tingkat pertumbuhan perekonomian yang tinggi di Benua Asia membuat nilai investasi yang masuk akan semakin tinggi tidak terkecuali di sembilan negara tersebut, sehingga berkontribusi dalam peningkatan FDI yang masuk ke wilayah tersebut. Menurut Kappel (2003) dalam C.J. Anwar et al. (2016) menyatakan bahwa keterbukaan dalam hal modal asing dapat 
mempercepat pertumbuhan ekonomi karena dengan investasi asing yang masuk dapat menambahkan faktor-faktor produksi domestik baik mengenai kuantitas maupun kualitas yang kemudian mendorong pertumbuhan ekonomi. Wilayah yang luas dan jumlah penduduk yang cukup besar di negara-negara dengan perekonomian berkembang di Asia mampu mendorong aliran masuk FDI ke negara-negara tersebut.

Hasil estimasi dari model jumlah limbah kota sembilan negara ekonomi berkembang menggunakan fixed effect model (FEM) dengan metode estimasi Weight least square (WLS) menghasilkan efek individu di setiap negara sebagai berikut :

Tabel 3. Efek Individu Setiap Negara

\begin{tabular}{|c|c|}
\hline Negara & Efek \\
\hline 1 & 2 \\
\hline Indonesia & -4.43581 \\
\hline Malaysia & 16.10462 \\
\hline Cina & -116.075 \\
\hline Kirgistan & 18.46956 \\
\hline Kazakhstan & 17.94816 \\
\hline Azerbaijan & 18.28289 \\
\hline Armenia & 18.82231 \\
\hline Turki & 10.3711 \\
\hline Singapura & 20.51244 \\
\hline
\end{tabular}

Efek individu menggambarkan karakteristik variabel tak bebas untuk setiap negara yang digunakan menjadi sampel ketika semua variabel bebas yang digunakan bernilai sama. Berdasarkan tabel 3, dapat dilihat bahwa Singapura merupakan negara yang memiliki efek individu terbesar yaitu 20,51244. Maksudnya adalah Negara Singapura memiliki potensi menjadi negara yang menghasilkan jumlah limbah kota yang tinggi dibanding negara lainnya. Sedangkan untuk negara yang memiliki nilai efek individu terendah adalah Negara Cina dengan nilai sebesar 116,0753 . Hal ini menunjukkan bahwa ketika variabel bebas bernilai sama pada setiap negara, maka Negara Cina memiliki potensi menjadi negara yang menghasilkan jumlah limbah kota yang rendah dibanding negara lainnya.

Tabel 4. Kepadatan Penduduk di Sembilan Negara Ekonomi Berkembang di Asia Tahun 2010-2017

\begin{tabular}{|l|r|r|r|r|r|r|r|r|}
\hline \multicolumn{1}{|c|}{ Negara } & \multicolumn{1}{c|}{2010} & \multicolumn{1}{c|}{2011} & \multicolumn{1}{c|}{2012} & \multicolumn{1}{c|}{2013} & \multicolumn{1}{c|}{2014} & \multicolumn{1}{c|}{2015} & \multicolumn{1}{c|}{2016} & \multicolumn{1}{c|}{2017} \\
\hline \multicolumn{1}{|c|}{2} & \multicolumn{1}{c|}{3} & \multicolumn{1}{c|}{4} & \multicolumn{1}{c|}{5} & \multicolumn{1}{c|}{6} & \multicolumn{1}{c|}{7} & \multicolumn{1}{c|}{8} & \multicolumn{1}{c|}{9} \\
\hline Indonesia & 133,5 & 135,3 & 137,1 & 139,0 & 140,8 & 142,6 & 144,4 & 146,1 \\
\hline Malaysia & 85,9 & 87,2 & 88,5 & 89,7 & 90,9 & 92,1 & 93,4 & 94,7 \\
\hline Cina & 142,5 & 143,2 & 143,9 & 144,6 & 145,3 & 146,1 & 146,9 & 147,7 \\
\hline Kirgistan & 28,4 & 28,8 & 29,2 & 29,8 & 30,4 & 31,1 & 31,7 & 32,3 \\
\hline Kazakhstan & 6,0 & 6,1 & 6,2 & 6,3 & 6,4 & 6,5 & 6,6 & 6,7 \\
\hline Azerbaijan & 109,5 & 111,0 & 112,5 & 113,9 & 115,3 & 116,7 & 118,0 & 119,2 \\
\hline Armenia & 101,1 & 101,0 & 101,3 & 101,8 & 102,3 & 102,8 & 103,1 & 103,4 \\
\hline Turki & 94,0 & 95,4 & 97,0 & 98,7 & 100,3 & 102,0 & 103,7 & 105,4 \\
\hline Singapura & 7231,8 & 7363,2 & 7524,7 & 7636,7 & 7714,7 & 7806,8 & 7908,7 & 7915,7 \\
\hline
\end{tabular}

Sumber : World Bank

Dari hasil diketahui bahwa efek individu Cina yang sangat rendah dan efek individu Singapura yang paling tinggi. Apabila ditinjau dari kepadatan penduduk dari Cina dan Singapura pada tabel 4, dapat dilihat bahwa Singapura memiliki tingkat kepadatan penduduk paling tinggi dibanding sembilan negara lainnya. Berbeda dengan Cina yang diketahui sebagai negara dengan populasi penduduk terbesar di dunia. Cina pada tahun 2010 memiliki nilai kepadatan penduduk sebesar 142,5 orang per $\mathrm{km}^{2}$ dan meningkat nilainya pada tahun 2017 menjadi 147,7 orang per km². Dari hal tersebut dapat menunjukkan alasan efek individu Singapura yang sangat tinggi dan efek individu Cina yang memiliki nilai paling kecil. 
Selain itu, dapat pula ditinjau dari jumlah limbah perkapita yang dihasilkan setiap tahunnya. Menurut World Bank, Singapura menghasilkan jumlah limbah perkapita 3,72 kg/ kapita/ hari, hal ini dapat dikaitkan dengan nilai PDB perkapita Singapura yang tinggi dibanding negara lainnya. Sedangkan Cina menghasilkan 0,43 kg/ kapita/ hari, apabila jumlah limbah perkapita Cina dikaitkan dengan PDB perkapita negaranya, maka dapat dilihat PDB perkapita Cina memiliki nilai yang rendah.

\section{KESIMPULAN}

Berdasarkan hasil analisis regresi data panel, dari keempat variabel bebas yang digunakan diperoleh dua variabel bebas yang signifikan dan positif mempengaruhi jumlah limbah kota yaitu variabel jumlah penduduk perkotaan serta FDI. Sedangkan untuk dua variabel lainnya yang tidak berpengaruh signifikan terhadap jumlah limbah kota adalah variabel jumlah wisataan mancanegara dan PDB perkapita.

\section{UCAPAN TERIMA KASIH}

Terima kasih kapada berbagai pihak yang telah membantu penelitian ini, terutama kapada Ibu Dr. Erni Tri Astuti, M.Math., selaku Direktur Politeknik Statistika STIS. Bapak Dr. Timbang Sirait, S.Stat, M.Si., selaku dosen pebimbing yang telah sangat membantu dalam penelitian ini. World Bank dan UNSD yang telah menyediakan data untuk penelitian. Serta kedua orang tua yang senantiasa memberikan doa dan dukungan.

\section{DAFTAR PUSTAKA}

Agamuthu, P., Fauziah, S. H., Khidzir, K. M., \& Aiza, A. N. (2007, September). Sustainable waste management Asian perspectives. In Proceedings of the international conference on sustainable solid waste management (Vol. 5, p.15).

Anwar, C. J. (2016). Faktor-Faktor Yang Mempengaruhi Foreign Direct Investment (Fdi) Di Kawasan Asia Tenggara. Media Trend, 11(2), 175-194.

Degli Antoni, G., \& Marzetti, G. V. (2019). Recycling and waste generation: an estimate of the source reduction effect of recycling programs. Ecological Economics, 161, 321-329.

Drysdale, C. (2018). World Economic Situation and Prospects 2018. New York: United Nations Department of Economic and Social Affairs.

Farhat, Sarah. (2018, 20 September). What a Waste : An Update Look into the Future of Solid Waste Management . World Bank. Diakses pada November 29, 2019, dari

https://www.worldbank.org/en/news/immersive-story/2018/09/20/what-a-waste-an updated-look-intothe-future-of-solid-waste-management

Foreign Direct Investment, Net (BOP, Current US\$)(2019, 20 Desember). Di World Bank. Diakses pada Februari 18, 2020, dari https://data.worldbank.org/indicator/BN.KLT.DINV.CD

GDP Percapita, Current US\$ (2019, 20 Desember). Di World Bank. Diakses pada Februari 18, 2020, dari https://data.worldbank.org/indicator/NY.GDP.PCAP.CD

Gnonlonfin, A., Kocoglu, Y., \& Peridy, N. (2017). Municipal solid waste and development: the Environmental Kuznets Curve evidence for Mediterranean countries. Region et Developpement, 45, 113-130.

Greene, W. H. Econometric Analysis" fifth edition, 2003.

Hsiao, C. (2014). Analysis of panel data. Cambridge university press.

International Tourism, Number of Arrival (2019, 20 Desember). Di World Bank. Diakses pada Februari 18, 2020, dari https://data.worldbank.org/indicator/ST.INT.ARVL

Jambeck, J. R., Geyer, R., Wilcox, C., Siegler, T. R., Perryman, M., Andrady, A., ... \& Law, K. L. (2015). Plastic waste inputs from land into the ocean. Science, 3476223), 768-771.

Karousakis, K. (2007). The economics and policy of municipal solid waste management (Doctoral dissertation, University of London).

Khajuria, A., Yamamoto, Y., \& Morioka, T. (2010). Estimation of municipal solid waste generation and landfill area in Asian developing countries. Journal of Environmental Biology, 31(5), 649-654.

Mathai, K. (2018). Regional Economic Outlook, April 2018, Asia and Pacific: Good Times, Uncertain Times: A Time to Prepare. International Monetary Fund. 
Mazzanti, M., \& Zoboli, R. (2008). Waste generation, incineration and landfill diversion: de-coupling trends, socio-economic drivers and policy effectiveness in the EU.

Modak, P., Pariatamby, A., Seadon, J., Bhada-Tata, P., \& International Solid Waste Association. (2017). Asia Waste Management Outlook.

Outlook, S. A. E. (2018). Economic Outlook for Southeast Asia, China and India OECD Development Centre.

Prolonged Uncertainty Weighs on Asia's Economy. (2019, 22 Oktober). Di International Monetary Fund. Diakses pada Desember 2, 2019, dari https://www.imf.org/en/News/Articles/2019/10/18/na102319prolonged uncertainty weighs-on-asias-economy

United Nations Environment Programme Questionnaire 2018 (2020, 3 Januari). Di United Nations Statistics Divisions. Diakses pada Februari 12, 2020, dari https://unstats.un.org/unsd/envstats/country files

Urban Population (2019, 20 Desember). Di World Bank. Diakses pada Februari 18, 2020, dari https://data.worldbank.org/indicator/SP.URB.TOTL

Wilson, D. (2015). Global waste management outlook: Summary for decision-makers. WIR - Foreign Direct Investment to developing Asia holds steady at \$476 bBillion In 2017, United Nations Reports (2018, 6 Juni). Di UNCTAD. Diakses pada Juni 30, 2020, dari https://unctad.org/en/pages/PressRelease.aspx?OriginalVersionID $=465$

World Bank. (2019). Trends in Solid Waste Management. Diakses pada November 28, 2019, dari http://datatopics.worldbank.org/what-a waste/trends in solid waste management.html

Xiao, Y., Bai, X., Ouyang, Z., Zheng, H., \& Xing, F. (2007). The composition, trend and impact of urban solid waste in Beijing. Environmental monitoring and assessment, 135(1-3), 21-30. 